\title{
Evolution of microstructure
} and electrochemical corrosion characteristics of cold compacted magnesium

\section{Vývoj mikrostruktury a elektrochemických korozních charakteristik práškového hořčíku lisovaného za studena}

\author{
Březina M. ${ }^{1}$, Doležal P. ${ }^{1,2}$, Krystýnová M. ${ }^{1}$, Minda $J .{ }^{1}$, Zapletal $J .^{2}$, Fintová $S .{ }^{1}$, Wasserbauer $J .{ }^{1}$ \\ ${ }^{1}$ Brno University of Technology, Faculty of Chemistry, Czech Republic \\ ${ }^{2}$ Brno University of Technology, Faculty of Mechanical Engineering, Czech Republic \\ E-mail: xcbrezinam@fch.vutbr.cz
}

The main advantage of magnesium and its alloys is high specific strength and biocompatibility. A modern approach to magnesium-based materials preparation is powder metallurgy. This technique allows preparation of new materials with a unique structure, chemical composition, and controlled porosity. In this study, cold compaction of magnesium powder was studied. Magnesium powder of average particle size of $30 \mathrm{um}$ was compacted applying pressures of $100 \mathrm{MPa}, 200 \mathrm{MPa}$, $300 \mathrm{MPa}, 400 \mathrm{MPa}$ and $500 \mathrm{MPa}$ at laboratory temperature. Influence of compacting pressure was studied with microstructural and electrochemical corrosion characteristics analysis. The resulting microstructure was studied in terms of light and electron microscopy. Obtained electrochemical characteristics were compared with those of wrought magnesium. Compacting pressure had a significant influence on microstructure and electrochemical characteristics of prepared bulk magnesium. With the increase in compaction pressure, the porosity decreased. Compacting pressures of $300 \mathrm{MPa}, 400 \mathrm{MPa}$ and $500 \mathrm{MPa}$ led to the similar microstructure of the prepared material. Polarization resistance of compacted magnesium was much lower and samples degraded faster when compared to wrought magnesium. Also, the corrosion degradation mechanism changed due to the microstructural differences between the material states.

\section{INTRODUCTION}

Powder metallurgy of magnesium and its alloys is nowadays widely studied technology as it has great potential of producing new lightweight construction materials as well as new perspective biomedical materials. Magnesium based composites, porous magnesium materials and magnesium alloys are mostly used in aerospace and automotive industry and also in medicine. Most common powder metallurgy technologies are cold pressing and sintering, hot pressing, isostatic pressing and
Hlavní výhodou hořčíku a jeho slitin je vysoká specifická pevnost a biokompatibilita. Moderni metodou prípravy hořčikových materiálů je prášková metalurgie. Tato metoda umožňuje prripravu nových materiálì s unikátní strukturou, chemickým složením a řizenou porositou. V této studii byl zkoumán objemový hořčíkový materiál připravený lisováním za studena. Hořčíkový prášek o středni velikosti částic $30 \mu \mathrm{m}$ byl lisován za laboratorni teploty tlakem $100 \mathrm{MPa}, 200 \mathrm{MPa}, 300 \mathrm{MPa}$, $400 \mathrm{MPa}$ a $500 \mathrm{MPa}$. Byl studován vliv lisovacího tlaku na mikrostrukturu a elektrochemické vlastnosti pripravených materiálů. Výsledná mikrostruktura byla studována pomocí světelné a elektronové mikroskopie. Elektrochemické charakteristiky byly srovnány s vlastnostmi tvářeného hořčíku. Lisovaci tlak měl zásadní vliv na mikrostrukturu a elektrochemické vlastnosti prípravených objemových materiálù. Se zvyšujicim se tlakem docházelo ke snižováni porozity, vzorky pripravené tlakem 300 MPa, 400 MPa a 500 MPa vykazovaly stejnou mikrostrukturu. Polarizační odpor připravených objemových materiálů byl mnohem nižši a vzorky degradovaly rychleji v porovnáni s tvářeným hořčikem. Došlo také ke zmèně charakteru degradace vlivem rozdilné mikrostruktury vzorkì. spark plasma sintering. The microstructure of materials prepared with these technologies can be subsequently modified using intensive plastic deformation methods such as extrusion, equal channel axial pressing (ECAP) and high-pressure torsion (HPT). Using these methods, hardness and strength of materials can be maximized [1-5].

Wide area of applications in aerospace and automotive industry of bulk magnesium materials is due to their high specific strength. The general approach to increase the strength of metallic materials is the reduction 
in grain size. This can be easily achieved using powder metallurgy followed by intensive plastic deformation techniques (extrusion, ECAP, HPT). This can be combined with solid solution strengthening of alloying elements and adding hard inorganic particles to powder mixture to produce magnesium based composites [6-10].

Low corrosion resistance of magnesium can be in special applications an advantage, as biodegradability of magnesium is in other words corrosion of magnesium in body fluids. Magnesium degrades into nontoxic products, and moreover, these products can enhance regeneration of damaged tissue. This provides a great advantage to conventional titanium or ceramic implants, which cannot degrade in the body and have to be removed. Polymerbased implants also undergo biodegradation, but they have much lower strength compared to magnesiumbased materials. Magnesium itself, however, degrades too rapidly, which causes rapid evolution of hydrogen and swift decrease in mechanical properties. For improvement of rapid degradation calcium and zinc are added as alloying elements and hydroxyapatite or fluorapatite are added as particle filler in magnesium based composites $[11,12]$.

Materials with controlled porosity fully compressed materials and materials with unique structure and chemical composition which could not be prepared using conventional casting methods are easily prepared via powder metallurgy. Another advantage of powder metallurgy is an almost waste-free fabrication of precise products. In general powder metallurgy process consists of pressing a prepared mixture of powders into a mould of precise dimensions. During compaction, metal particles are deformed and begin to connect to each other and cold welds are created. However, compacted product (green compact) has low strength and needs to be sintered into a final product. Sintering is a process of solid state connection of particles via diffusion. The

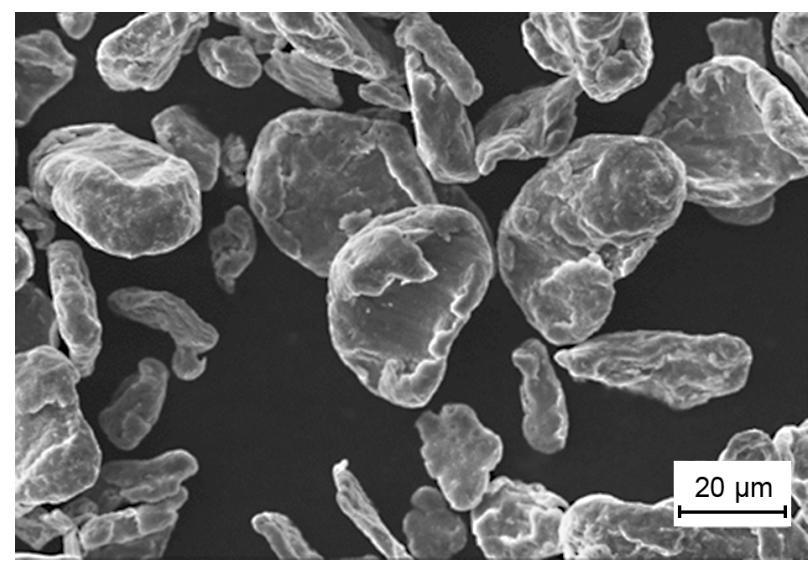

a) powder morphology and size distribution / morfologie distribuce velikostí prášku advantage of this process is better control of composition throughout the whole body of prepared material and limited segregation of elements [13-15].

Magnesium based powder metallurgy alloys and composites are widely studied, however, only a few studies focus $[16,17]$ on properties of bulk magnesium prepared by powder metallurgy and influence of high plastic deformation techniques. Therefore in this study, we focus on properties of bulk magnesium prepared via cold compaction from the point of microstructure and electrochemical corrosion properties.

\section{EXPERIMENTAL MATERIAL AND PROCEDURES}

\section{Base material}

Magnesium powder used in this study (Fig. 1) was irregularly shaped with the average particle size of approximately $30 \mu \mathrm{m}$. The purity of base material was $99.8 \%$ as declared by supplier Goodfellow, however, an oxide layer was found on the surface of powder particles using scanning electron microscope (SEM, ZEISS EVO LS 10) and energy dispersive spectroscopy (EDS). This layer of magnesium oxide is to be expected on the surface of magnesium and it was probably present on the particles from the powder preparation.

\section{Experimental procedure}

For metallographic and electrochemical analysis cylindrical compacts with $5 \mathrm{~mm}$ in height and $20 \mathrm{~mm}$ in diameter were prepared by cold compaction. $2.7 \mathrm{~g}$ of magnesium powder was inserted into steel die and compacted applying different uniaxial pressures; $100 \mathrm{MPa}$, $200 \mathrm{MPa}, 300 \mathrm{MPa}, 400 \mathrm{MPa}$ and $500 \mathrm{MPa}$. Compaction was carried out at laboratory temperature using Zwick

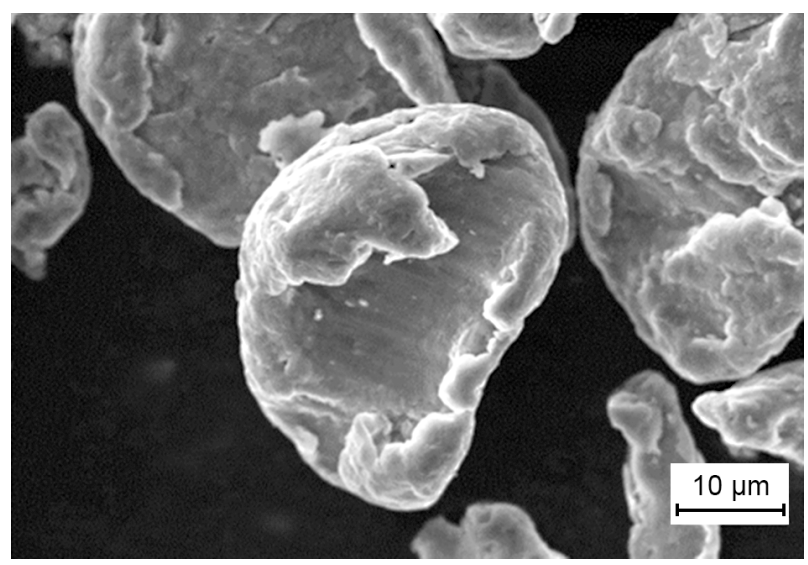

b) detail of the particle shape / detail tvaru práškových částic

Fig. 1. Magnesium powder, SEM

Obr. 1. Hořčíkový prášek, SEM 
Z250 Allround-Line machine equipped with sensitive extensometer MultiXtens set between pressing plates. Preparation of the magnesium powder into the die for compaction was carried out under nitrogen atmosphere to avoid further contamination of the powder by oxygen.

\section{Metallographic analysis}

The microstructure of prepared samples (compacts) was studied on cross-section using scanning electron microscope (SEM, ZEISS EVO LS 10) and light microscope (LM, Zeiss Axio Observer Z1m). Samples were mold into a polymeric resin at room temperature, ground and polished according to the standard procedure of metallographic samples preparation. The porosity of the compacted material was calculated from sample dimensions and weight.

\section{Electrochemical analysis}

Potentiostatic electrochemical impedance spectroscopy was used as a method to characterize the prepared magnesium based samples electrochemical corrosion characteristics. Three electrode cell was used for the measurement with Pt electrode as the counter electrode, calomel electrode as the reference electrode and the sample $\left(1 \mathrm{~cm}^{2}\right.$ exposed area) served as the working electrode. Sample surface was ground using 4000 sand paper and rinsed with isopropanol. Measurements were carried out in $0.9 \% \mathrm{NaCl}$ solution. Used frequency range was from $100 \mathrm{kHz}$ to $10 \mathrm{MHz}$, with a signal amplitude of $10 \mathrm{mV}$. All measurements were carried out at laboratory temperature. EIS data were obtained after $5 \mathrm{~min}, 1 \mathrm{~h}, 2 \mathrm{~h}, 4 \mathrm{~h}, 8 \mathrm{~h}, 12 \mathrm{~h}, 24 \mathrm{~h}, 48 \mathrm{~h}, 72 \mathrm{~h}$ and $96 \mathrm{~h}$ of immersion (where possible). The measurement time of one experiment was $25.8 \mathrm{~min}$. Electrochemical characteristics of prepared samples were compared to wrought magnesium with average grain size of $50 \mu \mathrm{m}$.

\section{RESULTS}

\section{Microstructure}

The microstructure of prepared samples obtained at different compacting pressures is shown in Fig. 2. Detail of the magnesium-based material microstructural evolution (powder particles deformation) due to the increased compaction pressure is obvious in Fig. 3. Samples prepared using $100 \mathrm{MPa}$ as the compacting pressure were highly porous and only limited particle deformation was visible Fig. 2a and Fig 3a. The high porosity of the sample is observable also by the presence of the resin used for metallographic specimen molding on the polished and etched cross-section (Fig. 3a). Open porosity of approximately $20 \%$ was calculated for the sample. Applying higher pressure than $100 \mathrm{MPa}$ led to microstructural changes. A significant decrease in porosity and high plastic deformation of powder particles occurred at higher pressures. Using a pressure of $200 \mathrm{MPa}$ resulted in powder particles plastic deformation due to the compaction and the porosity level decreased to approximately $10 \%$, Fig $2 \mathrm{~b}$. Compacting pressures of $300 \mathrm{MPa}, 400 \mathrm{MPa}$ and $500 \mathrm{MPa}$ led to the

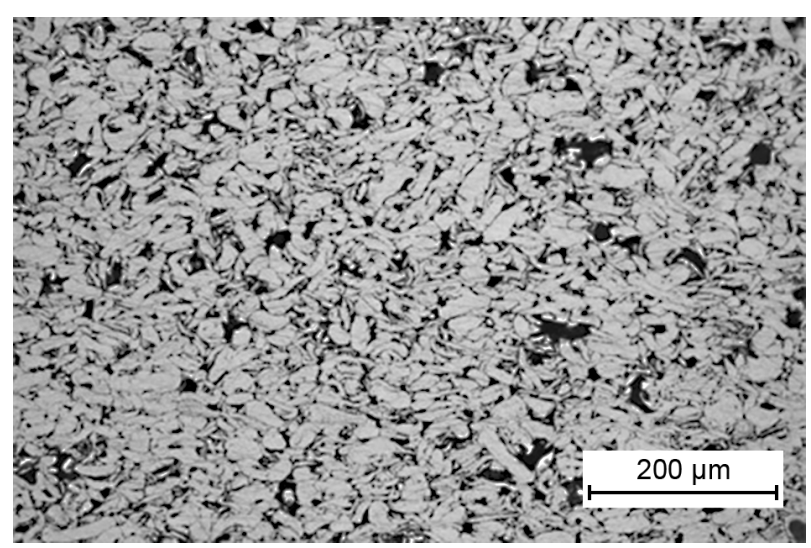

a) $100 \mathrm{MPa}$

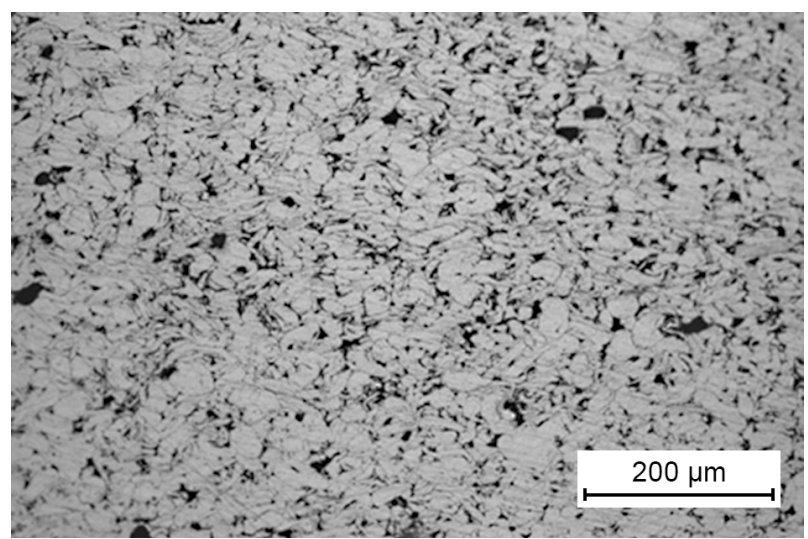

b) $200 \mathrm{MPa}$

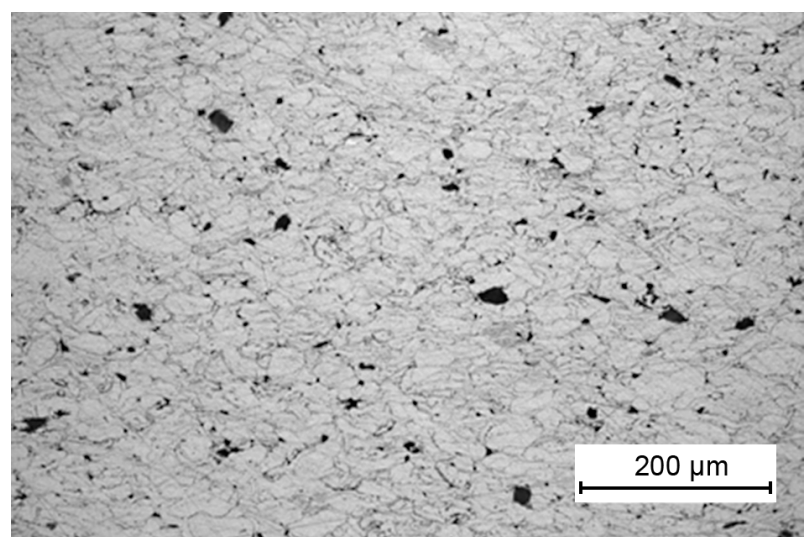

c) $300 \mathrm{MPa}$

Fig. 2. Evolution of microstructure of magnesium-based material prepared at different pressures, LM (continue on next page)

Obr. 2. Vývoj mikrostruktury hořčíkových materiálů pripravených prí různých tlacích, LM (pokračování na další stránce) 


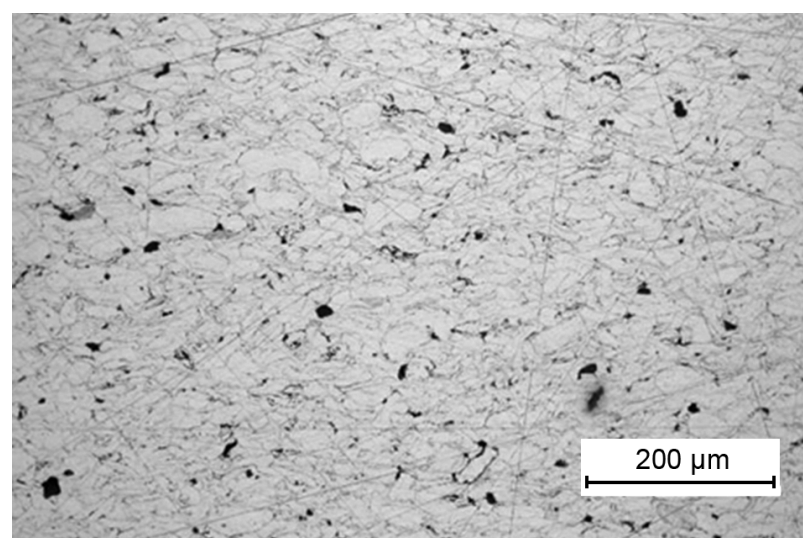

d) $400 \mathrm{MPa}$

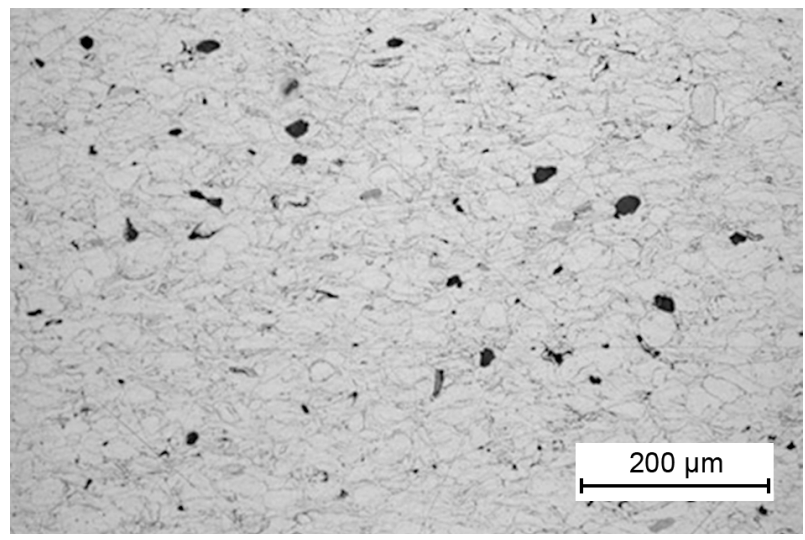

e) $500 \mathrm{MPa}$

Fig. 2. Evolution of microstructure of magnesium-based material prepared at different pressures, LM

Obr. 2. Vývoj mikrostruktury hořčíkových materiálů připravených při různých tlacích, $L M$

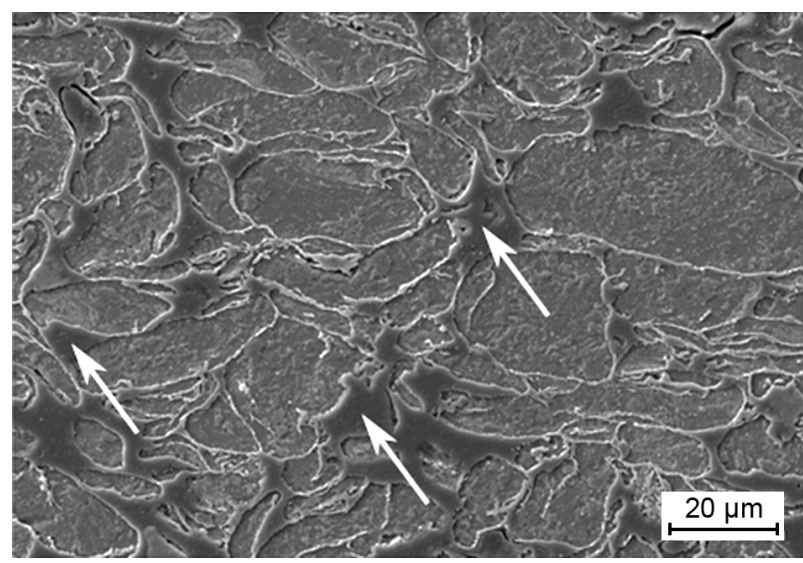

a) open porosity filled with resin / otevřená porozita s lisovací hmotou same microstructure with minimal differences in porosity (approximately $5 \%$ ) Fig. 2c, 2d and 2e respectively and Fig 3b, on this picture, small closed pores between powder grains are visible.

In Fig. 4 differences in compaction during sample preparation are represented. In the initial phase of compaction, the pressure increases very slowly, as particles reorganize to fill the free space between them. This almost linear increase in pressure is found under approximately $50 \mathrm{MPa}$, after this phase compacting pressure increases exponentially, as the plastic deformation takes place. Greatest change in compacting pressure lies in region between $100 \mathrm{MPa}$ and $300 \mathrm{MPa}$. Curves of compacting pressure of $300 \mathrm{MPa}, 400 \mathrm{MPa}$, and $500 \mathrm{MPa}$ are again almost linear near the end of compacting, which means that only minimal changes in microstructure take place after $300 \mathrm{MPa}$ compacting pressure, which is also visible in Fig. 2c, 2d, and 2e.

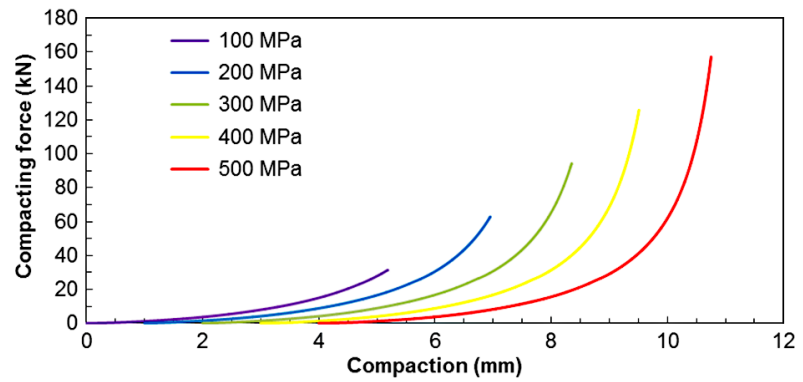

Fig. 4. Process of powder compaction, curves are shifted by $1 \mathrm{~mm}$ from each other for better visibility

Obr. 4. Proces zhutňování prášků, křivky jsou od sebe posunuty o $1 \mathrm{~mm}$ pro lepší viditelnost

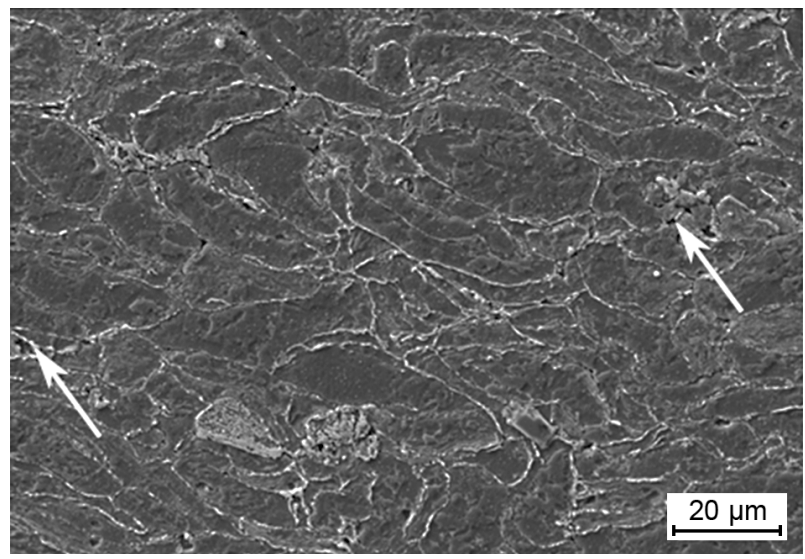

b) closed porosity / uzavřená porozita

Fig. 3. Microstructure of samples prepared at different compaction pressures, SEM, $5 \%$ Nital; marked areas: a) open porosity filled with resin, b) closed porosity

Obr. 3. Mikrostruktura vzorků připravených při různých tlacích, SEM, 5\% nital, označená místa: a) otevřená porozita s lisovací hmotou, b) uzavřená porozita 


\section{Electrochemical characterisation}

EIS measurements were performed on magnesium samples compacted at $500 \mathrm{MPa}$ and on wrought pure magnesium samples. Pure wrought magnesium was used as a basic material for obtained electrochemical characteristics comparison. Samples compacted at $500 \mathrm{MPa}$ were chosen due to their microstructure characteristic with the lowest porosity from whole the prepared samples. Nyquist plots for cold compacted and wrought magnesium are shown in Figs. 5 and 6 respectively. Equivalent circuits used for the plots evaluation are shown in Fig. 7. Determined electrochemical characteristics are given in Tables 1 and 2 .

Nyquist plots for compacted magnesium in $0.9 \%$ $\mathrm{NaCl}$ solution are given in Fig. 5. Two different plot characters can be seen in the graph. In the beginning of the measurement two loops were observed on the curve; for the evaluation of the plot was used an equivalent circuit shown in Fig. 7c. Only one loop was measured

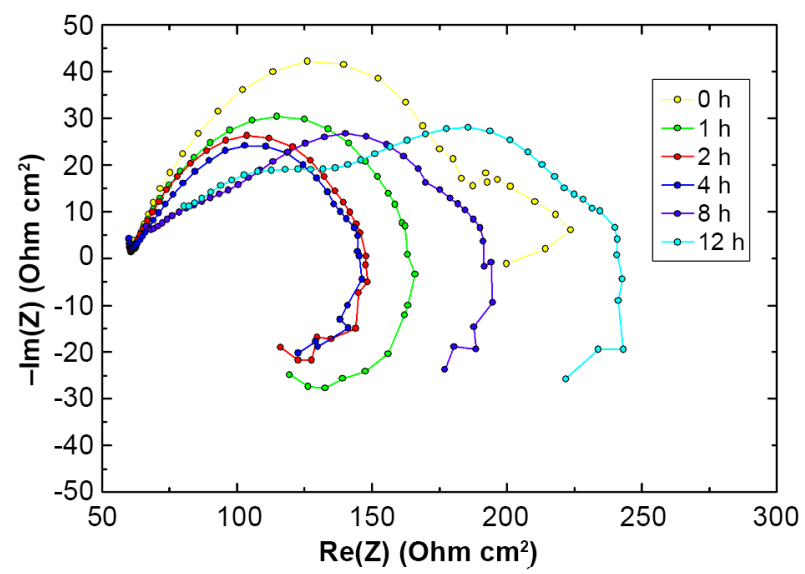

Fig. 5. Nyquist plots for cold compacted magnesium powder in $0.9 \% \mathrm{NaCl}$

Obr. 5. Nyquistovy grafy pro hořčíkový prášek zhutněnýza studena $v 0.9 \% \mathrm{NaCl}$

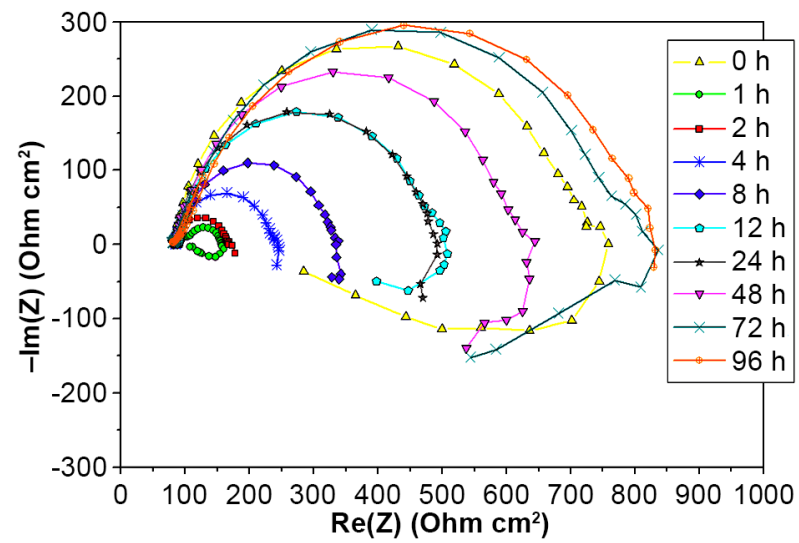

Fig. 6. Nyquist plots for wrought magnesium in $0.9 \% \mathrm{NaCl}$ Obr. 6. Nyquistovy grafy pro tvářený hořčík v $0.9 \% \mathrm{NaCl}$ in the case of compacted magnesium exposed to $\mathrm{NaCl}$ solution for the time longer than $1 \mathrm{~h}$ and the equivalent circuit shown in Fig. $7 \mathrm{~b}$ was used for the obtained data evaluation. After 8 hours of exposure two loops in the Nyquist plots were observed again. The experiment was stopped after 12 hours of material exposure to the used solution due to the rapid degradation of the experimental material. Polarization resistance of the material, Table 1, at the beginning of the experiment was $192 \Omega \mathrm{cm}^{2}$. Increasing the exposure time the value decreased to 86 $\Omega \mathrm{cm}^{2}$ at 4 hours of exposure. After 8 hours of exposure the polarization resistance increase and at 12 hours of exposure reached the value of $178 \Omega \mathrm{cm}^{2}$.

Nyquist plots for wrought magnesium in $0.9 \% \mathrm{NaCl}$ solution are given in Fig. 6. In this case, three different Nyquist loops types were measured. The equivalent circuit of the Fig. $7 \mathrm{~b}$ was chosen for the description of corrosion behavior in first $5 \mathrm{~min}$ of material exposure to the solution. At $1 \mathrm{~h}$, the equivalent circuit of the Fig. 7c was used. In this case, one extra capacitance loop was present in the graph. Further, in the interval 2-8 h, the simplified Randles cell was used (Fig. 7a) to analyze the obtained data. After $12 \mathrm{~h}$ of exposure the inductive

Tab. 1. Summary of polarisation resistances of cold compacted magnesium / Shrnutí polarizačních odporů lisovaného hořčíku

\begin{tabular}{|c|c|c|c|c|c|}
\hline $\begin{array}{c}\text { Time } \\
{[\mathrm{h}]}\end{array}$ & $\begin{array}{c}\mathbf{R}_{\mathrm{S}} \\
{\left[\mathbf{\mathbf { c m } ^ { 2 }}\right]}\end{array}$ & $\begin{array}{c}R_{1} \\
{\left[\Omega \mathbf{c m}^{2}\right]}\end{array}$ & $\begin{array}{c}R_{2} \\
{\left[\Omega \mathbf{~ c m}^{2}\right]}\end{array}$ & $\begin{array}{c}\mathbf{R}_{\mathbf{3}} \\
{\left[\mathbf{\mathbf { c m } ^ { 2 }}\right]}\end{array}$ & $\begin{array}{c}\mathbf{R}_{\mathrm{P}} \\
{\left[\mathbf{\Omega} \mathbf{c m}^{2}\right]}\end{array}$ \\
\hline 0 & 61 & 77 & 94 & 21 & 192 \\
\hline 1 & 61 & 49 & 57 & - & 107 \\
\hline 2 & 61 & 45 & 43 & - & 88 \\
\hline 4 & 62 & 49 & 37 & - & 86 \\
\hline 8 & 63 & 44 & 23 & 50 & 134 \\
\hline 12 & 61 & 59 & 103 & 16 & 178 \\
\hline
\end{tabular}

Tab. 2. Summary of polarisation resistances of wrought magnesium / Shrnutí polarizačních odporů tváreného hořčiku

\begin{tabular}{|c|c|c|c|c|c|}
\hline $\begin{array}{c}\text { Time } \\
{[\mathbf{h}]}\end{array}$ & $\begin{array}{c}\mathbf{R}_{\mathbf{S}} \\
{\left[\mathbf{\Omega} \mathbf{~ c m}^{2}\right]}\end{array}$ & $\begin{array}{c}\mathbf{R}_{\mathbf{1}} \\
{\left[\mathbf{\Omega} \mathbf{c m}^{2}\right]}\end{array}$ & $\begin{array}{c}\mathbf{R}_{\mathbf{2}} \\
{\left[\mathbf{\Omega} \mathbf{~ c m}^{2}\right]}\end{array}$ & $\begin{array}{c}\mathbf{R}_{\mathbf{3}} \\
{\left[\mathbf{\Omega} \mathbf{~ m}^{2}\right]}\end{array}$ & $\begin{array}{c}\mathbf{R}_{\mathbf{p}} \\
{\left[\mathbf{\Omega} \mathbf{~ c m}^{\mathbf{2}}\right]}\end{array}$ \\
\hline 0 & 82 & 312 & 324 & - & 635 \\
\hline 1 & 88 & 34 & 15 & 18 & 68 \\
\hline 2 & 84 & 81 & - & - & 81 \\
\hline 4 & 86 & 150 & - & - & 150 \\
\hline 8 & 89 & 240 & - & - & 240 \\
\hline 12 & 91 & 282 & 122 & - & 404 \\
\hline 24 & 84 & 401 & 54 & - & 455 \\
\hline 48 & 86 & 223 & 315 & - & 539 \\
\hline 72 & 91 & 438 & 270 & - & 708 \\
\hline 96 & 95 & 739 & - & - & 739 \\
\hline
\end{tabular}


behavior was found again and circuit from the Fig. $7 \mathrm{~b}$ was used for data analysis. This corrosion behavior was observed until the end of the experiment. Polarization resistance determined at the beginning of the experiment significantly decreased from the first EIS measurement until one hour, Table 2 . The polarization resistance grows gradually from the $1 \mathrm{~h}$ of the exposure to the end of the experiment. The maximum value of $\mathrm{Rp}$ was reached at the end of the experiment after $96 \mathrm{~h}$, Table 2.

Three equivalents circuits were used for fitting of the obtained Nyquist plots. Firstly, it was simplified Randles circuit, Fig. 7a, where $\mathrm{R}_{\mathrm{s}}$ represents solution resistance, $Q$ represents capacitance of double layer formed on the specimen surface and $\mathrm{R}_{\mathrm{p}}$ represents polarization resistance of formed double layer. Equivalent circuit shown in Fig $7 \mathrm{~b}$ consists of solution resistance $\mathrm{R}_{\mathrm{s}}, \mathrm{Q}_{1}$ is the capacitance of the present corrosion layer, $\mathrm{R}_{1}$ is the resistance of the capacitance part. Another time-independent part of this circuit is the inductive loop with inductance $\mathrm{L}_{2}$ and their resistance $R_{2}$. The resulting polarization resistance $R_{p}$ is the sum of $R_{1}$ and $R_{2}$ resistances. The last used equivalent circuit is in the Fig 7c. This equivalent circuit consists of three-time independent loops. There are two capacitance loops in high and low frequencies and one inductive

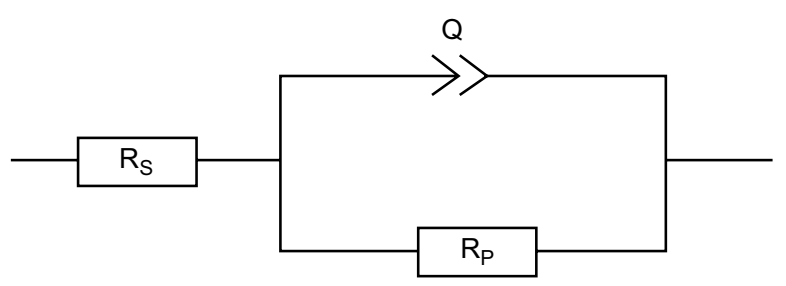

a)

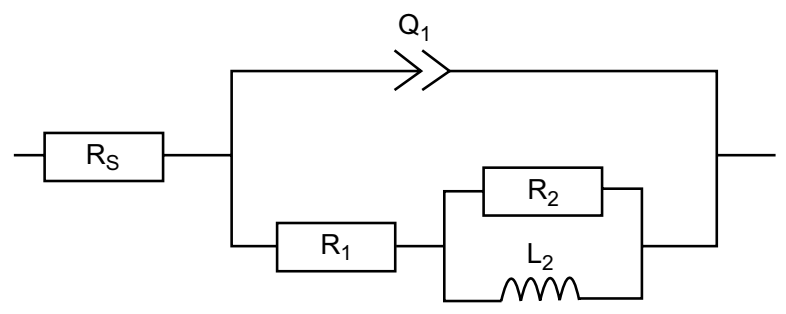

b)

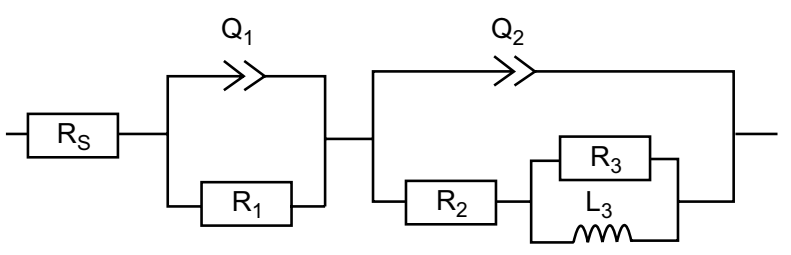

c)

Fig. 7. Equivalent circuits used for the Nyquist plots evaluation

Obr. 7. Ekvivalentní obvody použité pro vyhodnocení Nyquistových grafů loop. The elements $R_{s}$ is the solution resistance, $Q_{1}$ and $\mathrm{R}_{1}$ are capacitance and resistance of corrosion products barrier, $Q_{2}$ and $R_{2}$ are capacitance and resistance of the inner porous layer. Elements of the inductive loop are inductance $L$ and resistance of the inductor $R_{3}$.

\section{DISCUSSION}

Microstructure and electrochemical characteristic of prepared magnesium-based materials were observed to be highly dependent on the applied compacting pressure. Samples prepared using $100 \mathrm{MPa}$ as a compacting pressure showed minimum plastic deformation of powder particles, and the calculated porosity of these samples was approximately $20 \%$. This high porosity prohibited electrochemical measurements, as porosity this high is opened, therefore the electrolyte would flow through the sample. The high reactivity of magnesium would lead to fast material degradation.

Increasing compacting pressure to $200 \mathrm{MPa}$ led to significant changes in microstructure, as plastic deformation of powder particles was more severe. The porosity of these samples dropped to approximately onehalf of the values of previous samples $(100 \mathrm{MPa})$, however, the porosity was still opened, and therefore the electrochemical measurements were still impossible to conduct. Calculated porosity level is similar to [12]. The greatest change in the material takes place during 100 $\mathrm{MPa}$ compaction because in this region loose powder is shaped into porous compacted material. Compacting pressure of $200 \mathrm{MPa}$ yields observable changes in microstructure as the open porosity diminishes. Higher compacting pressures lead only to minimal changes in microstructure due to limited deformation possibilities of magnesium and absence of open porosity.

Using higher compaction pressure resulted in significant microstructural changes comparing to $200 \mathrm{MPa}$. Compacting pressures of $300 \mathrm{MPa}, 400 \mathrm{MPa}$ and 500 $\mathrm{MPa}$ resulted in similar microstructure and porosity. High compacting pressures led to severe plastic deformation of powder particles and decrease in porosity to approximately $5 \%$.

Behaviour of wrought magnesium after 5-minute immersion in the electrolyte $(0.9 \% \mathrm{NaCl})$ was probably connected with the development of corrosion products on the sample surface. The presence of inductive loop is probably caused by either interaction of corrosion products or impurities with the basic material, where the corrosion products or impurities are nobler than the base, or by the presence of pitting corrosion [18, 19]. After 1 hour of exposure, the chosen equivalent circuit corresponds to the creation of porous corrosion barrier on the sample surface. Following exposure of the sample 
surface to the electrolyte led to the additional creation of corrosion products on the sample surface. The stability of the corrosionprotecting layer was evident on the changed plots which led to using the simplified equivalent circuit. After $12 \mathrm{~h}$ of exposure, the corrosion behaviour of the wrought material changed again, an inductive loop was present due to partial damage to the protecting corrosion layer [20].

A similar evolution of the corrosion process was observed in the case of compressed material, however, less pronounced protecting against further material degradation was observed due to the surface oxidation, which prohibited magnesium particles full compaction, providing a porous layer through which the electrolyte progress further into the material. This could be connected with still present porosity, where the pores can act as corrosion initiation sites [19]. The physical meaning of this fact can be interpreted as electrolyte penetration into inner porous structure and creation of microcells due to ions concentration gradient (inductive loop) and formation of a double layer on the specimen substrate (capacitance loop). The response from the inner porous layer is not clear.

Based on the Nyquist plots the corrosion mechanism of the compacted magnesium can be described as follows. After 5 min exposure, an corrosion protective layer started to create, however, the layer was porous. Following exposure of the material to the corrosive environment led to the creation of protective layer, more compact comparing to the beginning of the measurements. After $8 \mathrm{~h}$ of exposure partial damage of corrosion layer occurred, this leads to measurement of one more capacitance loop. This phenomenon can be interpreted as a creation of two double layers, one between the solution and corrosion layer and other between corrosion layer and specimen surface.

Cold compacted materials significantly differ from wrought magnesium both from the point of microstructure and electrochemistry. The models of equivalent circuits are similar, however, their physical meaning differs. Generally, inductive loops, in the case of wrought magnesium, correspond with possible pitting corrosion mechanism or galvanic microcell creation between more noble corrosion products and magnesium $[18,19]$. In the case of cold compacted magnesium, the origin of inductive loops may correspond to ion concentration gradient in the porous structure, however, these two mechanisms cannot be distinguished using EIS method. From the corrosion point of view wrought magnesium exhibits higher polarization resistance than cold compacted magnesium. This is probably due to the presence of pores in the cold compressed magnesium microstructure enlarging the real sample surface, acting as a corrosion attack places and complicate the protecting corrosion layer creation.

\section{CONCLUSION}

Samples with different microstructure and porosity were prepared using uniaxial cold compaction process by the application of different pressures. Electrochemical corrosion characteristics of samples prepared using $500 \mathrm{MPa}$ were compared with those of wrought pure magnesium.

Influence of compacting pressure on the resulting microstructure and electrochemical characteristics are listed below:

- Compacting pressure has a significant influence on prepared bulk microstructure. Compacting pressure of $100 \mathrm{MPa}$ led to minimal plastic deformation of powder particles and the highest porosity (20\%). Powder particles deformation increased and porosity decreased with increasing compacting pressure. Applying compacting pressure in the range from 300 to $500 \mathrm{MPa}$ led to similar microstructure and porosity of obtained samples.

- EIS measurement revealed lower polarization resistance of compacted magnesium when compared to the wrought material. On the beginning of the exposure, the compacted material reached a value of the polarization resistance three times lower when compared to the wrought magnesium. The $\mathrm{R}_{\mathrm{p}}$, obtained for the compacted magnesium at 12 hours of the exposure to the corrosion environment, reached only less than a half of the value obtained for wrought material and the corrosion process was so pronounced, that the experiment had to be stopped.

- Differences in electrochemical corrosion characteristic were probably caused by the presence of pores in cold compacted magnesium microstructure, therefore larger exposed free surface was subjected to the corrosion environment. Also, a different mechanism of corrosion process can be connected with different behavior of two examined magnesium states.

\section{Acknowledgements}

This work was supported by project Nr. LO1211, Materials Research Centre at FCH BUT-Sustainability and Development (National Programme for Sustainability I, Ministry of Education, Youth and Sports)

\section{REFERENCES}

1. Witte, F., The history of biodegradable magnesium implants: A review. Acta Biomaterialia. 2010, 1680-1692.

2. Al-Zubaydi, A.,et al. Superplastic behaviour of AZ91 magnesium alloy processed by high-pressure torsion. Materials Science and Engineering A 2015, 637(1-2), 1-11. 
3. Lee, H., et al.Evolution in hardness and texture of a ZK60A magnesium alloy processed by high-pressure torsion. Materials Science and Engineering A 2015, 630, 90-98.

4. Suwas, S., Gottstein, S., Kumar. R., Evolution of crystallographic texture during equal channel angular extrusion (ECAE) and its effects on secondary processing of magnesium. Materials Science and Engineering 2007, 471 (12), 1-14.

5. Zhao, Y.F., et al. High strength $\mathrm{Mg}-\mathrm{Zn}-\mathrm{Ca}$ alloys prepared by atomization and hot pressing process. Materials Letters 2014, 118, 55-58.

6. Campo, R., et al, a další. Mechanical properties and corrosion behavior of Mg-HAP composites. Journal of the Mechanical Behavior of Biomedical Materials. 2014.

7. Zheng, Y.F., et al. In vitro degradation and cytotoxicity of $\mathrm{Mg} / \mathrm{Ca}$ composites produced by powder metallurgy. ActaBiomaterialia. 2010, 6 (5), 1783-1791.

8. Kang, M.,et al. Production and bio-corrosion resistance of porous magnesium with hydroxyapatite coating for biomedical applications. Materials Letters 2013, 108, 122-124.

9. Anish, R., Sivapragash, M., A Robertsingh, G. Compressive behaviour of $\mathrm{SiC} / \mathrm{ncsc}$ reinforced $\mathrm{Mg}$ composite processed through powder metallurgy route. Materials 2014, 63, 384-388.

10. Zhong, X.L., Wong, W.L.E., Gupta, M. Enhancing strength and ductility of magnesium by integrating it with aluminum nanoparticles. ActaMaterialia 2007, 55 (18), 6338-6344.

11. Liao, J., Hotta, M., Mori, Y. Improved corrosion resistance of a high-strength $\mathrm{Mg}-\mathrm{Al}-\mathrm{Mn}-\mathrm{Ca}$ magnesium alloy made by rapid solidification powder metallurgy. Materials Science and Engineering A 2012, 544, 10-20.
12. Čapek, J., Vojtěch, D. Effect of sintering conditions on the microstructural and mechanical characteristics of porous magnesium materials prepared by powder metallurgy. Materials Science and Engineering C 2014, 35, 21-28.

13. Čapek, J., Vojtěch, D., Properties of porous magnesium prepared by powder metallurgy. Materials Science and Engineering C 2013, 33 (1), 564-569.

14. Bi, Y., Zheng, Y., Li, Y. Microstructure and mechanical properties of sintered porous magnesium using polymethyl methacrylate as the space holder. Materials Letters 2015, 161, 583-586.

15. Rashad, M., et al. Improved mechanical proprieties of "magnesium based composites" with titanium-aluminum hybrids. Journal of Magnesium and Alloys 2015, 3 (1), 1-9.

16. I. Baker, D. Iliescu A Y. Liao. Containerless Consolidation of Mg Powders Using ECAE. Materials and Manufacturing Processes 2010, 25(12), 1381.

17. M.D. Pereda et al. Corrosion inhibition of powder metallurgy $\mathrm{Mg}$ by fluoride treatments. Acta Biomaterialia 2010, 6(5), 1772-1782.

18. M. Bukovina and B. Hadzima, "vplyv úpravy povrchu na elektrochemické charakteristiky horčíkovej zliatiny AE21", Transfer inovácii 2009, 15, 28-32.

19. G. Song, Corrosion of magnesium alloys, 1.. Philadelphia, PA: Woodhead Publishing, 2011.

20. B. Setzler and T. Fuller, "A Physics-Based Impedance Model of Proton Exchange Membrane Fuel Cells Exhibiting Low-Frequency Inductive Loops", Journal of the Electrochemical Society 2015, 162 (6), F519-F530. 